\title{
Subversively Accommodating: Feminist Bureaucrats and Gender Mainstreaming
}

\author{
Rosalind Eyben
}

\begin{abstract}
Is it possible to secure the desired policy action 'infusing' gender into existing ways of doing and organising things - and by so doing to incrementally secure real gains for women? Or will transformative policies for women's empowerment only be achieved through discursive and organisational transformation? But can the two be separated so neatly? Are there possibly unpredictable effects when feminist policy actors are on the one hand committed to changing discourse and power relations while on the other hand acting pragmatically to secure small instrumental changes? Taking international development organisations as the field of analysis, this article examines assumptions about policy change as a pathway of women's empowerment and goes on to explore a shift from a focus on institutional capability to one on actors and agency, and on strategies, tactics and manoeuvres.
\end{abstract}

'It's not that gender mainstreaming has failed but that we have failed to mainstream gender.' (Comment made at a meeting of the DAC GenderNet in July 2006)

\footnotetext{
1 Introduction

Gender mainstreaming was championed in the 1990 s as a strategy for infusing mainstream policy agendas with a gender perspective and transforming the institutions associated with them. Its radical promise came to be dimmed over the course of a decade in which it became increasingly evident that the desired results were simply not being achieved. The run-up to Beijing Plus Ten, in 2005, provoked a moment of significant reflection among international development researchers and practitioners. The overall conclusion was that the transformational promise of Beijing had failed to bring about a policy shift in favour of women's empowerment. By 2006, a spate of evaluations had depressed feminists working inside large development bureaucracies. Findings confirmed a failure to sustain the interest and commitment of governments and international development agencies in women's empowerment. Had they been too ambitious when seeking to transform
}

their bureaucracies? Would more modest objectives achieve more in the long run? Some feminists inside development agencies argued that buying into the prevailing discourse of efficiency and effectiveness might be the quicker route to their organisations taking 'women's empowerment' seriously.

As we approach Beijing Plus Fifteen, the mood has shifted. 'Gender equality' and 'women's empowerment' have re-established themselves in international development agencies as important goals to which senior management appears to be paying serious attention. The recent vote in the United Nations General Assembly to establish a UN 'gender entity' was an impressive result. Three years ago, many would not have predicted that so many governments, including the UK, would have lobbied so hard in the UN corridors to secure such an attitudinal change in international development policy. Today, feminist bureaucrats can argue that opting for an instrumentalist strategy is proving a success - at least within its own terms. It has influenced policy thinking. As one put it to me, 'Success is getting people to say things that you didn't think they were going to say'. 
Much of the debate concerning the effectiveness of mainstreaming is about whether it is understood as working within existing paradigms or changing them. Is it possible to secure the desired policy action by 'infusing' gender into existing ways of doing and organising things - and by so doing to incrementally secure real gains for women? Or will transformative policies for women's empowerment only be achieved through discursive and organisational transformation? Rather than reaching a firm view on this question, this article reflects on the limits and possibilities of the way in which 'policy' is understood in debates about gender mainstreaming. It draws on the author's engagement in policy processes and interviews with people in a range of aid organisations to examine the understandings that those involved in making, advocating and implementing policies for gender equality and women's empowerment bring to bear on their efforts. It examines assumptions about policy change as a pathway of women's empowerment and goes on to explore a shift from a focus on institutions to a focus on actors and agency, and on strategies, tactics and manoeuvres.

\section{The debate}

Most work on conceptualising policy in relation to women's empowerment has been undertaken in relation to the nation state. In that context Goetz and Hassim (2003) critique the liberal emphasis on the power of voice that does not consider the broader societal and institutional arrangements that shape the possibility of voice - an emphasis which also privileges bureaucratic arrangements for putting in place gender equality policies over the role of organised politics. Thus, they argue, successful policy change for women's empowerment depends upon three interrelated factors, namely the nature of civil society and the status and capacity of gender equality advocacy within it; the nature of the political system and political parties; and the nature and power of the state, including the bureaucratic machinery.

There has been a strong feminist tradition of questioning whether the bureaucratic form of organisation is by its very nature oppressive to women as the 'institutional arm of male dominance' (Calas and Smircich 1999; Ashcraft 2006). We might see bureaucracies as instruments of discipline that work to maintain the status quo, sometimes despite the best intentions of those working within for change. Thus feminists face the dilemma of engaging with the state machinery so as to change it, while devoting most of their time to performing the tasks that the bureaucracy requires of them, after which the machinery fails to deliver the hoped-for transformations.

Standing (2004) argues that donors' conventional approach to policy leads to their failing to think through how bureaucracies actually work in many aid-recipient countries, with gender 'focal points', tools and checklists becoming part of a selfperpetuating industry that depoliticises and makes technical what had begun as a political agenda. Gender mainstreaming objectives 'which place the onus on the bureaucracy to drive social transformation, especially where the political legitimacy of the institutions of government is already fragile, will therefore continue to run into the hot sands of evaporation' (2004: 84). She further argues that donors are naive about the causal links between policy intention and policy outcome, and unrealistically confident that gender and development planning can identify women's interests and devise pathways to advance them.

One reason why the idea of gender mainstreaming has not delivered on its expectations may be because feminist activists were over-influenced by the idea that policy is a package that could be transferred to another context without turning into something different. Where only token compliance is required, the transfer of policy may appear to have taken place, but if we understand policy as a site for resistance and contestation we might find the effects to be quite different. A concept of top-down linear policy implementation can seriously constrain an imaginative search for more appropriate understandings of the context and possible responses to that context. In a gender audit of the Department for International Development's (DFID) work in Malawi, Moser and her coauthors (2005) refer to 'evaporation and invisibilisation' of DFID's policy intentions as they were carried through in the programmes it partners with the Malawi Government. The authors consider the lack of internal capacity in DFID as a factor that shapes this outcome and note the need for staff training as well as additional tools and methods. This technical response to the problem is likely to be the one most acceptable to senior management - even if 
they do not implement the recommendations particularly in the absence of any political commitment from the Ministry and any strong external constituency for change. Without that political commitment and strong civil society mobilisation, it is very easy for gender equality work to slide down the slippery slope from an incremental approach to changing the paradigm, to becoming entirely instrumentalist. However, some would argue that even this is better than nothing; and in the longer term it may even produce the transformative effects unwanted by senior management, but secretly desired by the closet feminist.

In recent years, these arguments have gained ground. There has been a marked shift towards an instrumentalist perspective on gender equality and women's empowerment in the international development policy arena. The language of rights has disappeared from many official aid agencies' gender equality strategies. Those with gender briefs inside international agencies conclude that the only pragmatic way to work in this increasingly constrained environment is to fall back on the old efficiency arguments. As one participant in the DAC GenderNet meeting in June 2006 put it, 'The Paris Agenda is about increased aid, donors want countries to have economic growth as a result of that aid, and therefore if we want gender on the agenda we have to show how gender equality is important for growth'. Gender mainstreaming is becoming instrumental, based on the assumption that organisations will fail to deliver their other policy objectives, such as economic growth or girls' education, unless gender issues are addressed. The mainstreaming strategy being adopted de facto is to change procedures and introduce incentives rather than to change discourse, values and power relations. But can the two be separated so neatly? Are there possibly unpredictable effects when feminist policy actors are on the one hand committed to changing discourse and power relations, while on the other hand acting pragmatically to secure small instrumental changes?

\section{Insider activism}

Gender mainstreaming can be understood as concept, policy and a practical way of working. Much of the debate about gender mainstreaming has focused on the last of these and concluded that it has failed as an instrument of transformation, because it has had to work within existing paradigms and organisational forms. As such, it appears to have made only modest changes to the status quo. On the other hand, according to Porter and Sweetman (2005) there has been little evidence to date that a more radical approach, with an explicit transformative agenda, has been successful either. For some feminists 'failure' of mainstreaming in global development institutions has led to the conclusion that it is a waste of time and energy to engage directly any further with them. True (2003: 368), among others, disagrees:

The question is... not how feminist scholars and activists can avoid cooption by powerful institutions, but whether we can afford not to engage with such institutions, when the application of gender analysis in their policymaking is clearly having political effects beyond academic and feminist communities.

Rejecting gender mainstreaming as it is currently represented need not imply ignoring the potential of development organisations as a pathway of empowerment. Can we make that potential more visible by replacing our concern with gender mainstreaming, with addressing how power works in policy processes, and by focusing less on organisations and more on the agents that inhabit them, and on what they can do to realise some of the more radical potential of gender mainstreaming?

In a discussion of the quest for gender equality, Gita Sen (2006) asks whether social activism is the key to effective translation of research-based knowledge into policy and if so, what combinations of research and activism are required in different circumstances. For Sen, research relates to struggles over discourse, whereas activism is about struggles for institutional change. She notes that attempts to combine research with activism tend to be regarded askance, possibly because the disappearance of a neat division of labour places the actors in a position of competing for resources and recognition. She concludes that where social transformation is sought, both researchers and activists are essential but that the relationship between them can be complex.

In international feminist circles, Sen's understanding of 'activist' is common. Self- 
labelling as 'activist' by those working for policy change within large bureaucracies international non-governmental organisations (NGOs), governments and multilateral organisations - can be contentious with those whose activism is from within academia or the grassroots. Certainly, when I was in such a position, I saw myself as an activist, part of the women's movement, forming and working through transnational networks and employing very similar tactics. This controversy may concern a distinction between those who understand the political strength of activist networks to be their openness and potential to cut across formal state-society boundaries, and those who recognise bureaucrats as possible allies and donors but see them as on the other side of an unbridgeable divide.

The politics of making nets work for radical shifts in policy for women's empowerment require not only reflexivity, patience and stamina, but also 'consideration of the role and identity any one of us can most usefully assume in a particular context. This calls for thinking about the scope of possible action and about questions of power, vision and agency in which ... Everything in strategy has to be guessed at and presumed' (Sen 2006: 134).

In what follows I identify, in no particular order, a range of strategies and tactics that are being used by bureaucratic actors to negotiate change. I suggest that precisely because everything in strategy is largely unpredictable, we may not be able to determine in advance, for example, whether or not getting a senior manager to say something different will be a pathway of change.

\section{Negotiating change}

Discursive ambiguity has long been deliberately practised as a means to create and sustain a broad-based policy constituency and to manage conflicts within that constituency (Rydin 2005). Someone in a position of authority in a complex and dynamic environment might consciously choose discursive ambiguity to strengthen support for a vaguely defined common goal such as gender justice or women's empowerment. In such circumstances, the strategic actor facilitates space for others to make their own assessment of their situation and to choose and act upon the meanings they associate with this discursive goal, each from their own location and vantage point.
Such a strategy can generate creative responses of the kind the strategic actor is seeking, although she would not have been able in advance to say what she would have liked these to be.

Strategic ambiguity presents a rather different face and runs other risks in conditions of recognisable discursive differences. Here it 'provides a mode of exerting influence over stakeholders to stimulate desired behaviours necessary for the implementation of strategy' (Davenport and Leitch 2005: 1619). Some feminist bureaucrats in international development agencies have deliberately remained vague on what gender equality is and how to do it, in the hope that other actors such as economists in the World Bank may find themselves making choices concerning investment in 'women's economic empowerment' - in accordance with the Bank's Gender Action Plan - that eventually might lead to rights-based outcomes. For such a strategy to work it is essential to avoid clarity, including, for example, new guidance or principles that are too specific as to why gender equality is important. The risks of this approach arise from the capacity of another set of actors to impose their meaning in the absence of a countervailing narrative. Thus, the policy activist must feel reasonably confident in her institutional power analysis that ambiguity is the optimal means to safeguard room for manoeuvre, in circumstances where there is little chance of securing collective agreement to her desired meanings.

Social movement theory tells us of the importance of deconstructing terms and ideas that have become taken for granted so as to reveal that what was understood as 'natural' is no more than a social construct and thus amenable to change. In this way, an issue can be reframed so as to expand the imaginative horizon of what is possible to change. Issues that may not previously have been visible can then be put onto the policy agenda.

Opportunities to achieve this kind of outcome are enhanced if the wider discursive environment has become unstable, for example in times of religious or political upheaval when many ways of doing and believing are put into question. A number of contradictory trends in the global policy environment indicate that some policy actors are seizing the moment of discursive instability, as manifested by the recent resurgence of 
concern and interest in gender equality strategies in the context of the global economic crisis.

One such trend, arising from the invasion of Iraq and other incidents, is the growing scepticism regarding 'evidence-based policy', providing an opportunity to introduce other ways of knowing and acting for transformative change. Another trend that appears to contradict the first is the current emphasis - as manifested in the 'Paris Declaration on Aid Effectiveness', on technical managing for results that ignores political contexts and in which outcomes must be predetermined, 'concrete and measurable' (World Bank 2006). Another opposing trend is the increasing global policy interest in citizens' voice and participation - an interest that appears to provide an environment for a diversity of ways of knowing, in which inclusive and deliberative dialogues are the basis for responsive and appropriate policies in a dynamic and often unpredictable political world.

These contradictions are signs of an unstable discursive environment that reduces the potential for policy to sustain the status quo and opens up possibilities for reinforcing efforts to change the discourse. The implications for practice are that each episodic moment must be handled with full consciousness of the risk of reinforcing the status quo by offering no resistance to the dominant discourse, while being aware of the risk to credibility, job or research grant of manifesting open resistance. The strategic solution is to use what Clegg (1989) describes as 'outflanking manoeuvres' to reinforce discursive change and to further unsettle the status quo. The strength of this concept is its focus on political activity rather than, as in 'gender mainstreaming', on organisational change. It sees networks and alliances across and between organisations as the instruments for changing power, while formal organisations (perhaps with their own conservative networks) tend to be preservers of the status quo.

Feminists working inside international organisations can mobilise human and financial resources through alliance-building, being aware of and making use of networks within and beyond their own organisation to support their agenda. Alliances with civil society networks help the latter gain access to financial resources. Facilitating an alliance of lobbyists' access to policy spaces is strategic, provided the transformative agenda is a clear shared goal and that both the insider activist and the alliance leaders do not let the logic of the bureaucracy co-opt the alliance to its own agenda of conserving the status quo. For example, in 1985 an informal network of feminists lobbying the UK Government on women in development matters formalised itself into a development section within the Women's Organisations Interest Group (WOIG) of the National Council for Voluntary Organisations. In a path-breaking decision in 1986, the newly appointed Minister for Overseas Development, Chris Patten, instructed his officials to hold regular meetings with the WOIG; these meetings with the gender lobby continued up to the Fourth World Conference on Women held in 1995 in Beijing. During that time the WOIG transformed itself into the National Association of Women's Organisations (NAWO). ${ }^{1}$ Many of the civil servants who were persuaded to meet the lobby at our regular meetings saw it as adversarial, as indeed did some of the members of the lobby. Nevertheless, when working for DFID, I came to trust some of the leaders of the lobby in whom I could confide and to whom I could provide advice about how to handle the meetings for securing maximum policy advantages. Eventually, when I had the budget to do so, I arranged for the lobby to receive a government grant - 'to help with the preparations for Beijing' - which they and I interpreted as resources for more effectively lobbying DFID.

Networking has of course long been a staple of feminist global action (Tickner 2001; Moghadam 2005). It reflects a tradition of working through trust-based alliances in opposition to the dominant discourses and formal structures that the networks are resisting and seeking to change. Successful networking requires an intensive investment in relationships, which must be balanced with the time required by practitioners and researchers for their organisational and professional obligations.

The effective policy activist identifies the opportunities for introducing discursive shifts within the dominant rules of the game. The selective use of instrumentalist arguments can be part of a game plan for changing these rules. An example is the global campaign against violence to women. As part of that campaign, the 1993 World Development 
Report was used to demonstrate that such violence brought health and economic costs. Instrumentalist, as this approach seemed to some, within mainstream organisations such as DFID, it made violence against women at last a permissible subject of discussion, providing an entry point for subsequent recognition that this was a human rights issue. Equally, policy activists working inside mainstream organisations may keep an apparent distance from activists outside, while using the 'threat' of radical movements as an incentive for organisational change and new policy responses. When working in DFID, I frequently made the radical women's lobby out to be more of a menace to the status quo than it really was - 'we risk getting some really difficult parliamentary questions unless we change our position on this'.

Those who hope that international aid can be an instrument of social transformation see the emphasis on bureaucratic efficiency in the current aid architecture, embodied in the Paris Declaration, as a setback. Yet the discourse associated with the Declaration provides opportunities for creating discursive shifts in the rules of the game while appearing to demonstrate full commitment to the Paris agenda. The discourse is sufficiently ambiguous to provide the opportunity for imaginative engagement to turn Paris on its head. For example, the emphasis on results, broad-based ownership and accountability has been seen by some feminist bureaucrats as a chance to probe 'results for whom?' and 'accountability to whom?'.

The safest spaces for learning, sharing and plotting are those established for another more conservative purpose, which the feminist policy actor is then able to subvert. In addition to the conspiracy being less obvious because it is taking place within the existing organisational arrangements, it is likely that such spaces can be financed from existing budgets. As in Judo, the conspirators are making use of their opponents' resources. The activist's time is covered as part of her routine duties and she will write a conventional back-to-office report that omits the subversive component of the meeting. Nevertheless, constant attention is required to avoid the space being captured to perform its ostensible purpose. This may happen if gender specialists who are conservative instrumentalists rather than feminists seek to use the space for their own ends. A case in point is the conservative women's networks engaging in UN institutional spaces who seek to roll back global policy norms on reproductive rights (Mullings 2006).

In a situation of discursive instability, those working to sustain the status quo need to be as imaginatively active as those working for change. They are also likely to use many of these same tactics of outflanking through networks, exploiting contradictions and creating safe spaces for conspiracy. They may co-opt transformative discourse, using terms such as 'empowerment' to reinforce a conservative position (Cornwall and Brock 2005). They may even persuade feminists that they share the same goals and extract from them scarce financial and human resources for research and to get access to other policy spaces which they can then subvert - all in the guise of representing organisations or networks that share a transformative agenda and are just having to use instrumentalist language as a cover. Indeed, in some cases, policy activists may find themselves supporting the status quo while still believing they are changing things. Many would argue that feminist engagement with the World Bank is such a case (True 2003).

Of course, it is rarely so black and white. Actors' ideas change over time and they may become more or less radical depending on whom they associate with, and the effectiveness of communication efforts by the networks mobilising for change. Nevertheless, subversive steps may need to be taken to keep open spaces for such developments to take place. A wellpositioned policy activist responsible for developing the agenda and inviting the participants to an international meeting may feel institutionally compelled to invite the opposition - but can then suggest that the meeting could benefit from the presence of a 'critical friend' to reflect at an appropriate time on the key emerging issues. Another tactic is to draft the speech of the important personality invited to open the meeting and who, unaware of the issues being debated at the meeting, unknowingly provides discursive ammunition to neutralise the presentations of the opposition.

The opposition will of course use its own tactics, discursive or otherwise. The policy activist needs to be alert to the possibility of dirty tricks. Once, 
when I was leading a group of policy activists on a visit to lobby for change in a certain global organisation, I was told by someone from that organisation, hostile to the purpose of our visit, that he had just received a call from the directorgeneral's office that our scheduled meeting with the director-general - the highlight of our visit had been postponed for half an hour. When we therefore duly arrived 30 minutes later than originally arranged, we discovered that no such message had ever been sent and that we had lost the chance of meeting the director-general.

\section{Conclusion}

In her comprehensive review of gender mainstreaming (2005), Walby argues that unless organisations work through the contradictions between a desire to use gender for instrumental reasons and their desire to promote gender equality in its own right, gender mainstreaming will tend to support the status quo. However, I believe the issue to be more complex. These very contradictions can provide opportunities for policy change. Large organisations are heterogeneous 'battlefields of knowledge', full of contradictions and struggles; a policy activist would seek to manage and exploit these contradictions rather than resolve them. These contradictions between the instrumentalist and transformative agendas can be managed by using the instrumentalist agenda to make the status quo case for mainstreaming, while hoping and working towards more transformational goals, concerning which the activist stays silent except with co-conspirators.

Thinking about policy and social change in a manner that embraces rather than ignores contradictions calls for staying 'open to paradox'. This suggests that outflanking manoeuvres must be guided by improvisation. As in jazz, the

\section{Notes}

* I am most grateful to Andrea Cornwall for her support and editorial advice in drafting this article. players have a shared idea of what they might play, but the interaction of the instruments as they perform is different each time, so the score becomes a living reality rather than something determined in advance (Clegg et al. 2002). We might call this 'planned improvisation' that responds to the dynamics of the political environment. Because there is a shared vision but plans must constantly change, trust is a fundamental ingredient; who you choose to play with shapes the outcome. For feminist policy actors this requires an intensive investment in long-term relationships that often become supportive friendships.

Women's empowerment is often treated by international agencies as something that can be designed as a policy blueprint, rolled out and scaled up. This article suggests that what actually happens where policy is conceived, negotiated and shaped may be altogether different. This article seeks to show that individual agency matters. This is rarely recorded in the world of development policy, where change is attributed to the system, not to individuals. Paying closer attention to agency brings into focus the changes that can occur through bureaucratic activism. While feminists working for global social change need not support the discourse and practices of international development organisations, they should definitely watch for opportunities for these organisations to be pathways of empowerment. Despite strong misgivings concerning the depoliticisation of gender mainstreaming and the return of instrumentalist policies for women's empowerment, feminist researchers and civil society activists should not dismiss the efforts of feminists employed within development bureaucracies who struggle to keep women's rights on the international development agenda.

1 The present Gender and Development Network was subsequently established, in which gender specialists from the major British development NGOs participate. 


\section{References}

Ashcraft, K. (2006) 'Feminist-Bureaucratic Control and Other Adversarial Allies: Extending Organized Dissonance to the Practice of "New" Forms', Communication Monographs 73.1: 55-86

Calas, M. and Smircich, L. (1999) 'From the Woman's Point of View: Feminist Approaches to Organization Studies', in S. Clegg and C. Hardy (eds), Studying Organization, Theory and Method, London: Sage

Clegg, S. (1989) Frameworks of Power, London: Sage

Clegg, S.; Vierra da Cunha, J. and Pinha Cunha, M. (2002) 'Management Paradoxes: A Relational View', Human Relations 55.5: 483-503

Cornwall, A. and Brock, K. (2005) 'What do Buzzwords do for Development Policy? A Critical Look at "Participation", "Empowerment" and "Poverty Reduction", Third World Quarterly 26.7: 1043-60

Davenport, S. and Leitch, S. (2005) 'Circuits of Power in Practice: Strategic Ambiguity as Delegation of Authority', Organization Studies 25: 1603-23

Goetz, A-M. and Hassim, S. (2003) 'Introduction: Women in Power in Uganda and South Africa', in A-M. Goetz and S. Hassim (eds), No Shortcuts to Power: African Women in Politics and Policy Making, London: Zed Books

Moghadam, V. (2005) Globalizing Women:

Transnational Feminist Network, Baltimore: Johns Hopkins University Press
Moser, C.; M'Chaju-Liwewe, O.; Moser, A. and Ngwira, N. (2005) 'DFID Malawi Gender Audit: Evaporated, Invisibilised or Resisted?', report submitted to DFID, London:

Department for International Development

Mullings, B. (2006) 'Difference and Transnational Feminist Networks', International Studies Review 8: 112-15

Porter, F. and Sweetman, C. (2005) 'Editorial', Gender and Development 13.2: 2-10

Rydin, Y. (2005) 'Geographical Knowledge and Policy: The Positive Contribution of Discourse Studies', Area 37.1: 73-8

Sen, G. (2006) 'The Quest for Gender Equality', in P. Utting (ed.), Reclaiming Development Agendas. Knowledge, Power and International Policy Making, Basingstoke: UNRISD/Palgrave

Standing, H. (2004) 'Gender, Myth and Fable: The Perils of Mainstreaming in Sector Bureaucracies', IDS Bulletin 35.4: 82-8

Tickner, J.A. (2001) Gendering World Politics, New York: Columbia University Press

True, J. (2003) 'Mainstreaming Gender in Global Public Policy', International Feminist Journal of Politics 5.3: 368-96

Walby, S. (2005) 'Gender Mainstreaming: Productive Tensions in Theory and Practice', Social Politics 12.3: 321-43

World Bank (2006) Gender Equality as Smart Economics. A World Bank Group Gender Action Plan, Washington DC: World Bank

World Bank (1993) World Development Report, Washington DC: World Bank 